\title{
CEO Narcissism Personality Trait and its Effect on the Survival of Family-owned Businesses in South-South, Nigeria
}

\author{
Stanfast Suotonye Barnabas \\ Department of Management, \\ Faculty of Management Sciences, \\ Niger Delta University, Wilberforce Island, \\ Amassoma. Bayelsa State. \\ Nigeria. \\ Worlu G. O (PhD) \\ Department of Management, \\ Faculty of Management Sciences, \\ University of Port Harcourt, Choba, \\ Port Harcourt. Rivers State. \\ Nigeria.
}

\begin{abstract}
Family-owned businesses (FOBs) are prominent players both in regional and world economic development. They have continued to gain significance because they create new jobs, incubate new businesses, and drive entrepreneurial activities within communities. Despite these significant contributions of family-owned businesses to national development, very few FOBs survive to the second and third generations. A search of literature on the relationship between Chief Executive Officers (CEOs) Narcissisms Personality Trait and survival of these FOBs was scant. This quantitative study therefore critically examined CEO Narcissism personality traits and how it affects the survival of family-owned businesses in South-south Nigeria. The theoretical framework for this study was based on Upper Echelon Theory (UET). The study population consisted of 628 hotels in South-south region of Nigeria with 289 participants drawn from these hotels. Structural Equation Model used for data analysis revealed that CEO narcissism personality is critical and highly imperative factor in sustaining family-owned business operations and survival.
\end{abstract}

Key words: Personality trait, Survival, Narcissism, Adaptability, Dynamic Capability, Competitiveness

\subsection{Introduction}

The import of family-owned businesses (FOBs) in promoting economic development in the global economy cannot be over-emphasized. These businesses have continued to gain significance because they have helped economies reduce unemployment rate, nurture and encourage young entrepreneurs and their activities in the business space (Lee, Vargo, \& Seville, 2013; Perret, Burnett, \& Richardson, 2017).

Before the 90s, contributions of family-owned businesses to global economy was not obvious, however, the rise in unemployment and poverty rates across the globe within this period made FOBs prominent (Van der Westhuizen \& Garnett, 2014).

In South Africa, 80 percent of businesses are family-owned, and 60 percent of these FOBs are listed on the Johannesburg Stock Exchange (Ackerman \& Prichard, 2011). According to Maas and Van der Merve (2005), family-owned businesses greatly support growth in South African. Their continuous existence and/or survival should therefore not be treated with levity.

Despite these notable contributions of FOBs to global economies, only an insignificant number of them survive to the second and third generations (Asaju, Arome, \& Mukaila, 2014; Bednarz et al., 2017; Cai, 2015; Gaumer \& Shaffer, 2018; Ravindra Hewa Kuruppuge \& Gregar, 2017; Ravindra Hewa Kuruppuge \& Gregar, 2018; Mokhber et al., 2017; Perret et al., 2017; Stafford, Bhargava, Danes, Haynes, \& Brewton, 2010), a situation that has forced scholars to focus their attention on the study of the existence and longevity of FOBs.

Scholars have attributed the failure of family-owned businesses to a number of factors. Bednarz et al. (2017) opined that the survival of family-owned businesses can be guaranteed if there is a good succession plan and corporate governance practice in place. Adendorff, Boshoff, and Radloff (2005) further suggested that other causes of familyowned business failure are missed opportunities, unnecessary risks taking, and lack of skills to identify their strength and utilize same to their advantage (Venter, 2003, p. 34). 
This study attempts to close some gaps in literature. The study critically examined CEO Narcissism personality trait and its effect on the survival of family-owned businesses in South-south Nigeria. Furthermore, the study also provided some relief to the dearth of empirical based inquiry on CEO Narcissism personality trait and survival of family-owned businesses using Structural Equation Model (SEM) in south-south Nigeria.

The general business problem this research seeks to address is the continuous failure of family-owned businesses in South-South Nigeria, and the specific business problem this research seeks to address is the effect of CEO Narcissism personality trait on the survival of family-owned businesses in the South-South Region of Nigeria.

\subsection{Research Questions}

The study seeks to provide answer to the following research questions:

i. What is the relationship between narcissism and adaptability?

ii. What is the relationship between narcissism and dynamic capability?

iii. What is the relationship between narcissism and competitiveness?

\subsection{Research Hypotheses}

The following null research hypotheses were formulated and tested in the study:

H01: There is no significant relationship between narcissism and adaptability.

H02: There is no significant relationship between narcissism and dynamic capability.

H03: There is no significant relationship between narcissism and competitiveness.

\subsection{Literature Review}

\subsection{Theoretical Framework}

The Upper Echelon Theory (UET) provides anchor for this study. The upper echelon (UE) of an organization is regarded as the seat of power and the base where strategic decision makers reside (Hambrick \& Mason, 1984, p. 193). These decision makers otherwise known as business executives more often than not act or take decisions based on their personal interpretation of situations which ultimately affects organizational outcomes. Hambrick and Mason (1984) noted that managers and/or business executives form their perception from observations, personal experience, and psychological characteristics. The emphasis of UET is that executives' experiences, values, and personalities affect their interpretations of situations and choices (Hambrick, 2007). The Upper Echelon Theory suggests that organizational outcomes are rooted in CEOs human capital (HC) and their personality factors (Hiller \& Hambrick, 2005). CEOs human capital (HC) and personality factors are critical factors in determining their decisions and shaping firm strategy.

Human capital is a firm's major competitive advantage and it is generally defined as knowledge and skills contained in people (Coff, 2002). Proponents of Upper echelon theory noted that CEO human capital is demonstrated by their cognitive expressed by certain demographic factors (Carpenter et al., 2004; Finkelstein, Hambrick, \& Cannella, 1996).

UET provides support for this study because it examines how the personality traits of top business executives' impact on firms' outcomes.

\subsection{The Concept of Narcissism Personality Trait}

Allport (1937) defined personality as "an individual's psychological systems that describes his uniqueness within his environment" as cited in (Robbins, Judge, \& Sanghi, 2007, p. 106). It is our interactive and reactive behavioural traits that we consistently exhibit (Zopiatis \& Constanti, 2012).

Tantrabundit and Narkbunnum (2018) defined personality as the pattern of an individual's thoughts and behaviours that are consistently exhibited over time. These behaviours influence the individual's attitudes and reactions to other people. A CEO often has a disproportionate, sometimes dominating influence on his firm, hence, organization's must be careful in their choice of a chief executive officer (Wang \& Chen, 2019).

Proponents of the upper echelon theory view personality as the observable behaviours of a CEO that influence his decision and overall organizational performance. Personality comprises multiple dimensions and all dimensions take eff ect simultaneously when a CEO makes decisions. They opined that one main challenge that restrains researchers from studying impact of CEO personality comprehensively is the difficulty in obtaining data about CEOs' personality particularly in the public sector but private sector CEOs tend to be more willing to answer questionnaires about their personality, and their responses may be devoid of social desirability bias (Wang \& Chen, 2019). 
Chollet et al. (2016) noted that personality of CEO drives their firm's outcomes such as profitability and growth. Personality influences how people perceive their environment and interpret information accurately without bias. Personality of CEOs determine how they also view their environment (Porac, Thomas, \& Baden- Fuller, 2011).

von den Driesch, Da Costa, Flatten, and Brettel (2015) noted that Chief Executive Officers (CEOs) are in position to shape organizational outcomes because of their influence in fostering and deploying dynamic capabilities (Hiller \& Hambrick, 2005). Upper echelon (UE) theory, first introduced by Hambrick and Mason (1984), highlights that CEO experience and personality influence their individual decisions and thus also their firms' strategic decisions. This happens because CEO perceptions become the pre-dominant basis for organizational action as relevant causeeffect relationships are often unknown and unavailable when environmental uncertainty is high (Finkelstein et al., 1996; Kaplan, 2008).

Schneider and Smith $(2004$, p. 347) define personality broadly to refer to those individual attributes that "give form, structure, and consistency to people's behaviour over time and situations". Personality traits are patterns of thought, emotion, and consistent behaviour in an individual.

The competitive nature of business environment has made it extremely necessary for well-trained and experienced CEOs to pilot the affairs of family-owned firms for their continuous growth and survival (Kelleci, Lambrechts, Voordeckers, \& Huybrechts, 2019) and the personality traits of CEOs determine their firms' outcome. Understanding a CEO Personality which describes his preferred way of behaving allows for prediction of his possible reaction to situations per time (Kelleci et al., 2019). Personality is an individual's peculiar pattern of behaviour that describes his/her reaction and interpretation of life's situations. These traits exposes the individual's preferred ways of behaving, thinking, and feeling (Saville, 2016), and they influence how individuals consistently interpret and respond to situations (Feist, Feist, \& Roberts, 2017). Thus, insight into someone's personality allows easy prediction of that individual's preferred behaviour in a given situation (Sherman, Nave, \& Funder, 2010).

Studies of CEO personality have noted that CEO's personality affects his/her firm's strategic decisions, structure, and performance (Hambrick, 2007; Schein, 2010). This explains why Hambrick, Finkelstein, and Mooney (2005, p. 503) emphasized the import of studying executive personality.

Scholars of personality have identified five underlying dimensions of personality to include (a) Conscientiousness (b) Agreeableness (c) Neuroticism (d) Openness to Experience and (e) Extraversion (Chollet et al., 2016; Harrison et al., 2019; Lin \& Rababah, 2014; O’Reilly III, Caldwell, Chatman, \& Doerr, 2014; Tantrabundit \& Narkbunnum, 2018).

Conscientiousness (C): This personality trait measures how an individual controls, regulates, and direct his/her impulses. Persons with high conscientiousness are focused and concentrate on limited goals but strive hard to reach those goals (Howard \& Howard, 1995). These type of high conscientiousness people are well-organized, show selfdiscipline, behave dutifully, act orderly and are more competent, responsible and thorough. Individual with low conscientiousness are flexible, more impulsive and easy to persuade or convince to change task (Howard \& Howard, 1995). Low conscientiousness people are careless, impulsive, and lack direction (Costa Jr, 1992).

Agreeableness (A): This personality trait measures differences associated with social harmony in friendly and cooperative behaviour (Howard \& Howard, 1995). Individuals with high agreeableness are fundamentally altruistic, sympathetic, eager to help others, and believe others are equally willing to help them. Persons with low agreeableness are egocentric, skeptical of others' intentions, and they compete with others rather than co-operate with them (Costa Jr, 1992).

Neuroticism (N) (Emotional Stability): This personality trait measures an individual's affective and emotional control. Low neuroticism indicates emotional stability. These individuals are calm, even-tempered, relaxed and able to face stressful situations without becoming upset (McCrae \& Costa Jr, 1997), while persons with high neuroticism are experiencing negative emotions such as fear, sadness, embarrassment, anger, guilt and disgust (Howard \& Howard, 1995). They are unstable, worried, temperamental, sad, reactive and easily bothered by external stimuli (Howard \& Howard, 1995).

Openness to Experience $(\mathrm{O})$ : This personality trait measures an individual's desire for experience and knowledge. It is associated with willingness to improve intellectual capacity, acquire new ideas, disposition to imbibing new cultural belief, attitude towards acquisition of new educational skills, curiosity, creativity, alternative ideas and perspectives. Individuals with high openness to experience are considered to have broad interests, to be liberal and like novelty, whereas individuals with low openness to experience are preservers who are conventional, conservative and prefers familiarity (Howard \& Howard, 1995). Openness to experience is concerned with intellectualism, sophistication, aesthetics, feelings, actions, ideas, values and independence of mind (Costa Jr, 1992). 
Extraversion (E): This personality trait measures an individual's extraversion-introversion tendencies (Costa Jr, 1992). Individual with high extraversion are extraverts.

Extraversion associates with adventurous, assertiveness, frankness, sociable, talkative, physically and verbally active. Individuals with low extraversion are introverts. They are independent, reserved, steady, quiet, shy, unsociable and prefers to be alone. Persons in between these two extremes are indifferent between social situations and solitude (Howard \& Howard, 1995).

Several scholars have classified personality traits as the Big five (5) represented with the acronym CANOE but this study seeks to examine other dimension of personality trait which is narcissism.

\subsection{Narcissism}

Narcissism personality trait was first articulated by Walder in 1925 (Campbell \& Miller, 2011). According to Walder, individuals with Narcissistic personality feel superior to others, they are concerned about themselves, they lack empathy towards others, and they are sexually attached to the opposite sex strictly because of physical pleasure; they pay less attention to emotional intimacy. Freud in 1931 drawing from the works of Walder described narcissist as one who is primarily focused on self-preservation. The individual is highly independent, a go-getter, out-spoken and bold, aggressive, and not keen about maintaining intimate relationships. The psychoanalyst Wilhelm Reich (1933/1949) added that phallic narcissist are self-confident, arrogant, haughtiness, coldness, and aggressive (Campbell \& Miller, 2011). Narcissistic personality trait describes people who are interested in their own success and they have feeling of self-importance; this affects their decision-making ability and interactions with others. Narcissists hardly build or maintain relationship with others. They are manipulative and lack empathy. They crave for attention and admiration yet they lack compassion towards other. CEOs with narcissistic trait fantasies about being influential, famous; they exaggerate their abilities, talents, and accomplishments; crave for admiration and acknowledgment; preoccupied with beauty, love, power, and/or success; believing that the world owes them something; and they lack empathy toward others (Chabrol, Van Leeuwen, Rodgers, \& Séjourné, 2009).

CEOs with behaviours described above are Overt Narcissist because they are loud, arrogant, and insensitive to the plight of others. Their behaviours are easily observed by others (Capron, 2004; Kim, Namkoong, Ku, \& Kim, 2008; Tamborski \& Brown, 2011).

Covert Narcissist behaviour are less obvious to others. People go into relationship with covert narcissists because of their subtle nature only to be hurt later (Capron, 2004; Miller et al., 2016; Tamborski \& Brown, 2011).

Some of the general traits and patterns described above displayed by covert narcissist in their everyday interactions do not require clinical diagnosis; and knowing these traits is key in empowering those inter-facing and interacting with the covert narcissist in maintaining healthy relationship (Capron, 2004; Chabrol et al., 2009; Miller et al., 2016; Paulhus \& Williams, 2002; Tamborski \& Brown, 2011).

\subsection{The Concept of Organizational Survival}

The business environment is characterized with uncertainties and unanticipated events that threaten the survival of organizations. These uncertainties if not properly managed begin with organizations experiencing decrease in sales and profitability. The continuous occurrence of these negative trends can interrupt/affect an organization's quest to continue conducting its operations to meet stakeholders' expectations; a situation that often results in the organization's loss of goodwill, reputation, and customers. The effect of poorly managing these unanticipated events will challenge organization's very existence and survival thus leading to its eventual collapse (Fleming, 2012).

Díez-Martín, Prado-Roman, and Blanco-González (2013) opined that organization need departmental support to survive. That is, it must function like an open system (Reitz, 2012). The operation of organizations is greatly influenced by regulatory authorities, customers, suppliers, shareholders, competitors, etc. and as such family-owned businesses need to relate effectively with stakeholders to get the needed support for their corporate existence and survival. The measures of survival of family-owned businesses to be examined in this study are adaptability, dynamic capability, and competitiveness.

\subsection{Adaptability}

Adaptability as used in modern day management parlance derived its origin from biology. Adaptability in management refers to an organization's capacity to adjust its processes, procedures, structures, and systems in order to face environmental changes (Denison, 1990). It entails the taking of proactive and/or calculated actions that is geared towards meeting demands of stakeholders. The business environment is complex and characterized with uncertainties; and organizations need to always develop strategies that will reposition them for these environmental uncertainties. 
According to Reeves and Deimler (2012), globalization and technological advancement have brought about business challenges that have forced organizations to consistently improve their operational strategies.

Reeves and Deimler (2012) studied competitive advantage of top companies in the US and their study revealed that $2 \%$ of companies dropped from the top three rankings in their industry in 1960 . By 2008 , this figure had risen to $14 \%$. The study further revealed that market share leader was not the profitability leader within the period. As at $1950,34 \%$ of market share leaders were also the profitability leaders in the same industry but this figure dropped to just $7 \%$ in 2007. Business executives today can hardly identify their competitors.

\subsection{Dynamic Capability}

Globalization and technological innovations have forced firms across the globe to be innovative because of the challenges posed by external forces (Bendig, Strese, Flatten, da Costa, \& Brettel, 2018). Organizations have to frequently and continuously realign their operations with current realities in the global environment and adopt strategies that will reposition them to compete favourably (Breznik \& Lahovnik, 2014). The quest for organizations to remain competitive in the turbulent business environment necessitated scholars like Teece, Pisano, and Shuen (1997) to introduce dynamic capabilities (DCs) as a strategy to deliver desired results.

\subsection{Competitiveness}

The term competitiveness has no universally acceptable definition. It can however be described as the capacity of an organization to produce and sell quality products at the best possible price that maximizes return on the resources used in the production process. Through the price offering in relation to its competitors, the organization builds competitive positions that enable superior economic performance.

The World Economic Forum in Lausanne 1994, described competitiveness as "the ability of a country or company to create greater wealth than competitors on the world market" (Forum, 1994).

\subsection{Methodology}

The population of this study is the complete list of SMEs, particularly hotels in south-south, Nigeria, which constitute the sampling Frame. The sampling units were drawn from the list of members of Hotel Proprietors Association in each of the six (6) south-south states (Akwa Ibom, Bayelsa, Cross Rivers, Delta, Edo and Rivers State) of Nigeria (these are informal sector hotels). The population of the study is six hundred and twenty-eight (628).

This study utilised purposeful sampling to identify the family-owned hotels from the list of Hotels Proprietors Association in each of the six (6) south-south states of Nigeria (these are informal sector hotels). Simple random sampling was used with the aid of random numbers, to ensure each member of the population has equal chance of being selected.

\subsection{Results and Discussion}

\section{Hypothesis One}

$\mathrm{HO}_{1}$ : There is no significant relationship between narcissism and adaptability.

Table 1 below illustrates the analysis for the association between narcissism and adaptability of FOBs in SouthSouth Nigeria, where $\beta=-0.09, \mathrm{r}=-0.09, \mathrm{R}^{2}=0.009$ and $\mathrm{p}=0.000$. The findings show a very negative and significant association between both variables (where $\beta=-0.09<0.3, r=-0.09<0.7$ and $p=0.000<0.05$ ). Thus, based on the criteria for null hypothetical statement acceptance $(\beta>0.3, r>0.7$ and $p>0.05)$; or rejection $(\beta<0.3$, $\mathrm{r}<0.7$ and $\mathrm{p}<0.05$ ), the null hypothesis is rejected and restate that there is a negative but significant relationship between narcissism and adaptability of FOBs in South-South Nigeria. Therefore, $\mathrm{H}_{1}$ was not supported.

\section{Hypothesis Two}

$\mathrm{HO}_{2}$ : There is no significant relationship between narcissism and dynamic capability

Table 2 below illustrates the analysis for the association between narcissism and dynamic capability of FOBs in South-South Nigeria, where $\beta=-0.68, r=-0.23, R^{2}=0.47$ and $p=0.000$. The findings show a very negative and significant association between both variables (where $\beta=-0.68<0.3, r=-0.23<0.7$ and $p=0.000<0.05$ ). Thus, based on the criteria for null hypothetical statement acceptance $(\beta>0.3, r>0.7$ and $p>0.05)$; or rejection $(\beta<0.3$, $\mathrm{r}<0.7$ and $\mathrm{p}<0.05$ ), the null hypothesis is rejected and restate that there is a negative but significant relationship between narcissism and dynamic capability of FOBs in South-South Nigeria. Therefore, $\mathrm{HO}_{2}$ was not supported.

\section{Hypothesis Three}

$\mathrm{HO}_{3}$ : There is no significant relationship between narcissism and competitiveness. 
Table 3 below illustrates the analysis for the association between narcissism and competitiveness of FOBs in South-South Nigeria, where $\beta=-0.12, r=-0.09, R^{2}=0.01$ and $p=0.000$. The findings show a very negative and significant association between both variables (where $\beta=-0.12<0.3, \mathrm{r}=-0.09<0.7$ and $\mathrm{p}=0.000<0.05$ ).

Thus, based on the criteria for null hypothetical statement acceptance $(\beta>0.3, r>0.7$ and $p>0.05)$; or rejection $(\beta<0.3, r<0.7$ and $\mathrm{p}<0.05)$, the null hypothesis is rejected and restate that there is a negative but significant relationship between narcissism and competitiveness of FOBs in South-South Nigeria. Therefore, $\mathrm{HO}_{3}$ was not supported.

Presented in table 4 below is the result for the tests of hypotheses 1,2 and 3 which assessed the extent to which narcissism impacts on the measures of Survival FOBs.

The first hypothesis $\left(\mathrm{HO}_{1}\right)$, states that there is no significant relationship between narcissism and adaptability. However, table 4 indicates that narcissism has a negative and significant relationship with adaptability of hotels in South-south Nigeria $(\beta=-0.09, \mathrm{r}=-0.09$ and $\mathrm{p}=0.000<0.005)$. Thus, $\mathrm{H}_{1}$ was not supported. The evidence presents narcissism as a strong predictor of adaptability in hotels of South-south, Nigeria. Statistically, it shows that when narcissism goes up by 1 standard deviation, adaptability goes down by 0.09 standard deviation. In other words, when narcissism goes up by 1 , adaptability goes down by 0.09 . The regression weight for narcissism in the prediction of adaptability is significantly different from zero at the 0.005 level (two-tailed). That is, increase in narcissism is associated with decrease in adaptability. This finding aligns with Chabrol et al. (2009) who found that CEOs with narcissistic trait have a sense of self-importance or grandiosity; preoccupied with beauty, love, power, and/or success; an exaggerated sense of being unique; and believing that the world owes them something. This evidence is supported by the result of the studies where it was opined that narcissist CEOs are loud, arrogant, and insensitive to the needs of others and always thirsty for compliments and this will adversely affect an organization's ability to adapt to changes in the environment (Capron, 2004; Kim et al., 2008; Tamborski \& Brown, 2011). According to McAdams (2016), U.S. president Donald Trump is adjudged to posse narcissism personality trait. $\mathrm{He}$ is ambitious/self-serving, highly-dominant, self-confident, prone to act impulsively and ultimately, he is more attuned to his own needs than to those of others. President Donald Trump considers himself potentially one of the greatest presidents in the history of the United States and as such, despite overwhelming evidences against him on national issues president Donald Trump will not change his position.

The second hypothesis $\left(\mathrm{HO}_{2}\right)$, states that there is no significant relationship between narcissism and dynamic capability. However, table 4 suggests that narcissism has a negative and significant relationship with dynamic capability of hotels in South-south, Nigeria $(\beta=-0.68, \mathrm{r}=-0.23$ and $\mathrm{p}=0.000<0.005)$. Thus, $\mathrm{H}_{2}$ was not supported. This means that the presence of narcissism in South-south hotels of Nigeria, will not lead to dynamic capability within the hotels. Statistically, it shows that when narcissism goes up by 1 standard deviation, dynamic capability goes down by -0.68 standard deviation. In other words, when narcissism goes up by 1 , dynamic capability goes down by -0.68 . The regression weight for narcissism in the prediction of dynamic capability is significantly different from zero at the 0.005 level (two-tailed). That is, increase in narcissism will lead to decrease in dynamic capability. This finding agrees with Campbell and Miller (2011) who noted a strong evidence that narcissism personality trait negatively influence firm's dynamic capability because CEOs with high narcissism personality trait are highly independent, extraverted, not easily intimidated, and aggressive. In a study of top 25 most narcissistic CEOs in Tech using their level of exploitativeness, leadership, superiority, and self-absorption and/or Self-admiration, Larry Page founder of Google was reported as the most narcissistic CEO and Jeff Weiner founder of LinkedIn's as the least narcissistic CEO (Jackson, 2013).

The third hypothesis $\left(\mathrm{HO}_{3}\right)$, states that there is no significant relationship between narcissism and competitiveness. However, table 4 also suggests that narcissism has a negative and significant relationship with competitiveness of hotels in South-south, Nigeria $(\beta=-0.12, \mathrm{r}=-0.09$ and $\mathrm{p}=0.000<0.005)$. Thus, $\mathrm{H}_{3}$ was not supported. This means that narcissism will not lead to competitiveness of hotels in South-south, Nigeria. Statistically, it shows that when narcissism goes up by 1 standard deviation, competitiveness goes down by -0.12 standard deviation. In other words, when narcissism goes up by 1 , competitiveness goes down by -0.12 . The regression weight for narcissism in the prediction of competitiveness is significantly different from zero at the 0.005 level (two-tailed). This implies increase in narcissism will lead to decrease in competitiveness. This finding is consistent with Pincus and Lukowitsky (2010) who found a strong evidence that narcissist do not have drive and/or zeal to adopt new and competitive strategies; and maintain cordial relationship with stakeholders. They noted that CEOs with narcissism personality trait are inept at building and nurturing emotional bond with others. Thus, they seldom maintain bonds with others because their energy is always focused on themselves. This finding, also aligns with Capron (2004) who found that narcissists have a sense of lack of partnership or reciprocity in their relationships hence they find it difficult to stay with same people for too long.

These outcomes present narcissism as a negative but significant predictor and antecedent of Survival FOBs in South-South Nigeria. Thus, all three null hypothetical statements of no significant relationships between narcissism 
and the measures of Survival FOBs in South-South Nigeria are rejected based on the statistical evidence shown in the tables below.

The results suggest that CEOs with narcissistic trait such as having a sense of self-importance or grandiosity; fantasies about being influential, famous, and/or important; do not play a critical role in enhancing the organization's ability to adjust its processes, procedures, structures, and systems in response to environmental changes; the organization's ability to build and reconfigure competencies to address rapidly changing environments; and its ability to satisfy and retain family and staff members to the second generation. Thus, the findings show as follows:

Narcissism does not drive and enhance hotels' capacity to anticipate problems in advance and develop satisfactory and timely solutions which makes them highly adaptive in South-south Nigeria.

Narcissism does not enhance hotels' capacity to build and reconfigure competencies that will address rapidly changing environmental challenges, thus, strengthening their dynamic capability within the South-south region of Nigeria.

Narcissism personality trait amongst hotels' CEOs will not make hotels in South-south Nigeria adopt competitive strategies, attract family and staff members with requisite experience, creative and innovative capabilities, and ensure cordial relationship with all relevant stakeholders.

\subsection{Conclusion and Recommendations}

The conclusions for this study reiterate the position of its adopted theoretical frameworks. The implications follow that the organizational outcomes are rooted in CEOs human capital (HC) as well as their personality factors. This aligns with the theoretical assertions and predictions of the upper echelon view. The evidence emphasizes that decision makers otherwise known as business executives more often than not act or take decisions based on their personal interpretation of situations, they form their perception based on their observations, personal experience, as well as psychological characteristics. Business executives' experiences, values, and personalities greatly influence their interpretations of the situations they face and, in turn, affect their choices (Hambrick, 2007). Organizational outcomes are rooted in CEOs human capital (HC) and their personality factor which determines their decisions and shaping firm strategy.

In practice, CEO narcissism personality impacts considerably on an organization's adaptability, dynamic capability and competitiveness in a volatile business environment. However, as revealed in this study, such impact is linked to the CEO's expectations, self-perceptions, values, and attitudes which eventually help to predict an individual's reactions to other people, problems and stress. Organizations thrive and survive on their proactive ability to predict environmental changes and adjust their processes and procedures to meet current realities and provide quality, distinct and convenient services to their customers; and this is same within the Nigerian hospitality industry.

With the increase of hotels in south-south Nigeria and the steep competition within the hospitality industry, the chances of survival grow thinner as more organizations will go into extinction. Therefore, CEOs need to compete favourably by adapting to their environment. These factors draw significantly from the CEOs ability to perceive their environment accurately and interpret information free of bias.

The implications for family-owned businesses is that, in today's business environment, well-trained and experienced CEOs is crucial for growth and survival of family-owned firms (Kelleci et al., 2019) and the personality traits of these CEOs determine their firms' outcome. CEO personality emphasized on the imperatives of narcissism influences the functionality of the organization. Its strength draws on the fact that it focuses on the gaps and challenges within the market, and through its openness to change and desire to standout, drives for closing such gaps through narcissism.

With reference to the findings and conclusions of this study regarding the relationship between CEO Narcissism personality and survival of family-owned businesses in South-south Nigeria, the study recommend as follows:

CEOs of family-owned hotels should focus on their personality traits and observe the inadequacies in their thoughts, feelings, social adjustments, and behavioural pattern that have impede their ability to determine unique adjustments in the business environment. This is with a view to ensuring that their narcissism personality traits of having a grand sense of self-importance, manipulative tendencies, lack of empathy, lack of compassion, exaggerating their abilities, talents, and accomplishments, exaggerated sense of being unique, exploiting others to get what they want (no matter how it impacts others), etc which are counterproductive to the organization are dropped. 
Figure 1: Relationship between narcissism and adaptability of FOBs in South-South Nigeria

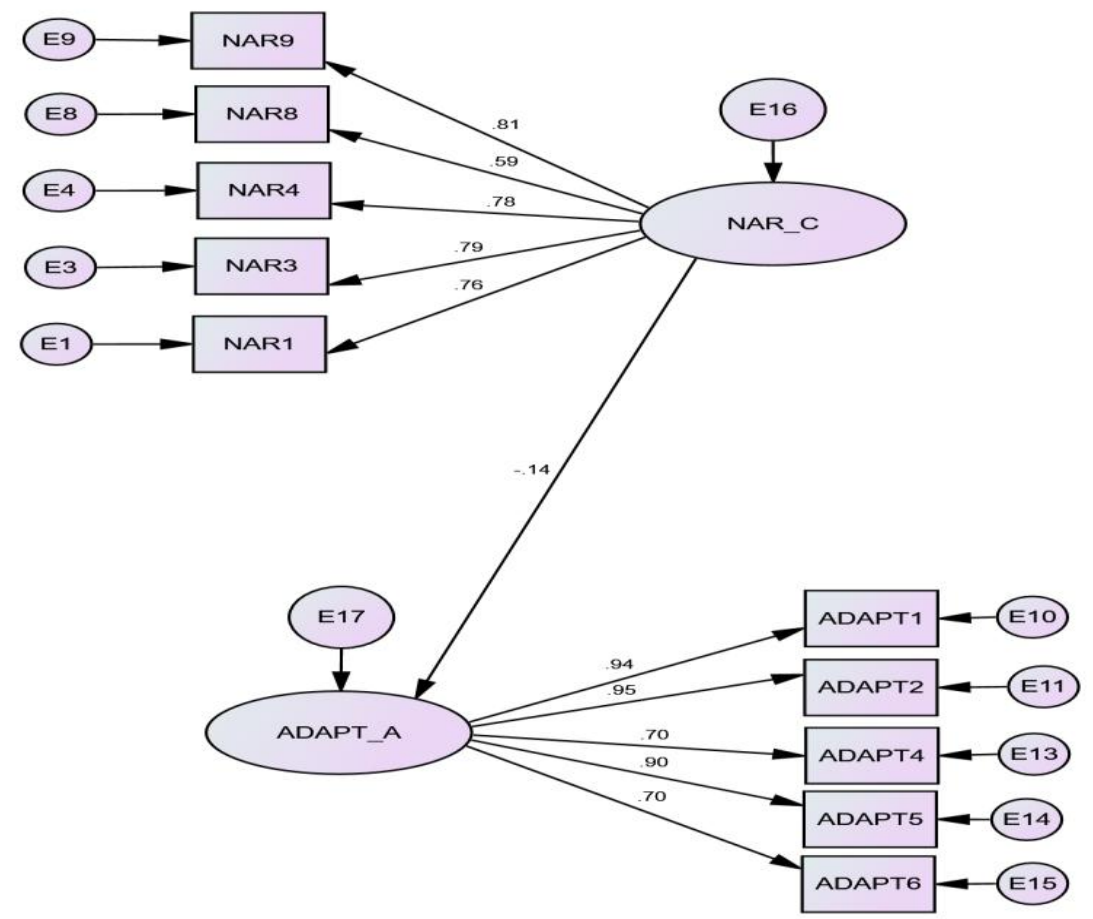

Table 1: Relationship between narcissism and adaptability of FOBs in South-South Nigeria

\begin{tabular}{|c|c|c|c|c|c|c|}
\hline $\begin{array}{l}\text { Mediation } \\
\text { Stage }\end{array}$ & Relationship & $\begin{array}{l}\text { Chi Square(df), } \\
\text { Significance }\end{array}$ & NFI & TLI & CFI & RMSEA \\
\hline $\begin{array}{l}\text { NAR } \rightarrow \text { ADAP } \\
(\text { Hypothesis } 1 \text { ) }\end{array}$ & $\begin{array}{l}\text { Narcissism and } \\
\text { Adaptability }\end{array}$ & $\begin{array}{l}(20 \mathrm{df}) \\
=83.752 \\
P=0.000\end{array}$ & 0.97 & 0.95 & 0.97 & 0.11 \\
\hline $\begin{array}{l}\text { Regression } \\
\text { Weights }\end{array}$ & $\begin{array}{l}\text { Std. } \\
\text { Beta }(\beta)\end{array}$ & $\begin{array}{l}\text { Squared } \\
\text { Multiple } \\
\text { correlation }\left(\mathbf{R}^{2}\right)\end{array}$ & CMIN/DF & & & \\
\hline-0.089 & -0.096 & 0.009 & 4.188 & & & \\
\hline
\end{tabular}

Source: Amos 26.0 output on research data, 2020

Figure 2: Relationship between narcissism and Dynamic Capability of FOBs in South-South Nigeria

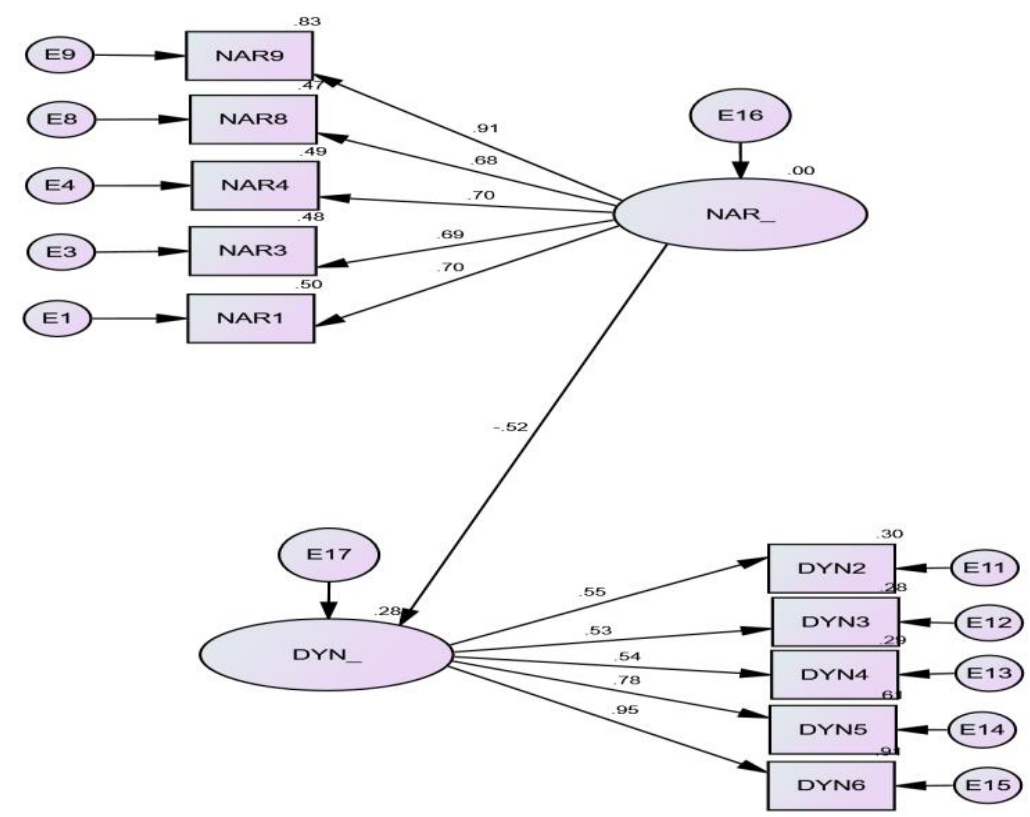


Table 2: Relationship between narcissism and dynamic capability of FOBs in South-South Nigeria

\begin{tabular}{|c|c|c|c|c|c|c|}
\hline Mediation Stage & Relationship & $\begin{array}{l}\text { Chi Square(df), } \\
\text { Significance }\end{array}$ & NFI & TLI & CFI & RMSEA \\
\hline $\begin{array}{l}\text { NAR } \rightarrow \text { DYN } \\
(\text { Hypothesis 2) }\end{array}$ & $\begin{array}{l}\text { Narcissism and } \\
\text { Dynamic Capability }\end{array}$ & $\begin{array}{l}(15 \mathrm{df}) \\
=55.816 \\
\mathrm{P}<0.000\end{array}$ & 0.97 & 0.94 & 0.98 & 0.10 \\
\hline $\begin{array}{l}\text { Regression } \\
\text { Weights }\end{array}$ & $\begin{array}{l}\text { Std. } \\
\text { Beta ( } \beta)\end{array}$ & $\begin{array}{l}\text { Squared Multiple } \\
\text { correlation }\left(\mathbf{R}^{2}\right)\end{array}$ & CMIN/DF & & & \\
\hline-0.228 & -0.682 & 0.466 & 3.721 & & & \\
\hline
\end{tabular}

Source: Amos 26.0 output on research data, 2020

Figure 3: Relationship between narcissism and Competitiveness of FOBs in South-South Nigeria

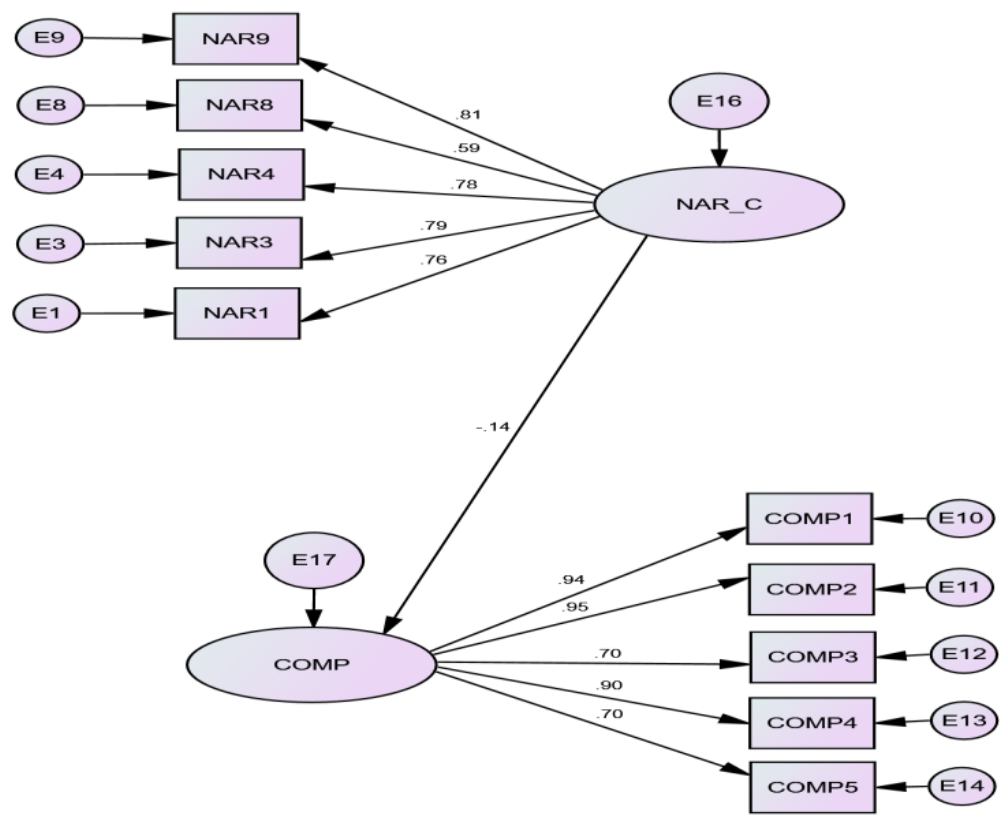

Table 3: Relationship between narcissism and competitiveness of FOBs in South-South Nigeria

\begin{tabular}{|l|l|l|l|l|l|l|}
\hline Mediation Stage & Relationship & $\begin{array}{l}\text { Chi Square(df), } \\
\text { Significance }\end{array}$ & NFI & TLI & CFI & RMSEA \\
\hline $\begin{array}{l}\text { NAR } \rightarrow \text { COMP } \\
\text { (Hypothesis 3) }\end{array}$ & $\begin{array}{l}\text { Narcissism and } \\
\text { Dynamic Capability }\end{array}$ & $\begin{array}{l}(21 \mathrm{df}) \\
=80.918, \\
\mathrm{P}=0.000\end{array}$ & 0.97 & 0.95 & 0.98 & 0.10 \\
\hline Regression Weights & $\begin{array}{l}\text { Std. } \\
\text { Beta }(\boldsymbol{\beta})\end{array}$ & $\begin{array}{l}\text { Squared Multiple } \\
\text { correlation }\left(\mathbf{R}^{2}\right)\end{array}$ & CMIN/DF & & & \\
\hline-0.091 & -0.118 & 0.014 & 3.853 & & & \\
\hline
\end{tabular}

Source: Amos 26.0 output on research data, 2020

Table 4: Summary of Result on the Tests of Hypotheses $\mathrm{HO}_{1} ; \mathrm{HO}_{2}$ and $\mathrm{HO}_{3}$

\begin{tabular}{|c|c|c|c|c|c|c|c|c|c|}
\hline $\mathbf{S} / \mathbf{N}$ & $\begin{array}{l}\text { Mediation Stage } \\
\text { (Null Hypothesis) }\end{array}$ & Relationship & $\begin{array}{l}\text { Std. } \\
\text { Beta }\end{array}$ & $\begin{array}{l}\text { Actual } \\
\text { Beta }\end{array}$ & $\mathbf{R}^{2}$ & CMIN/DF & $\mathbf{P}$ & Remark & Decision \\
\hline 1 & $\begin{array}{l}X \rightarrow Y \\
\left(\mathrm{HO}_{1}\right)\end{array}$ & $\begin{array}{ll}\text { Narcissism } & \text { and } \\
\text { Adaptability } & \end{array}$ & -0.09 & -0.09 & 0.01 & 4.19 & 0.000 & $\begin{array}{l}\text { Negative } \\
\text { and Significant }\end{array}$ & Not Supported \\
\hline 2 & $\begin{array}{l}\mathrm{X} \rightarrow \mathrm{Y} \\
\left(\mathrm{HO}_{2}\right)\end{array}$ & $\begin{array}{l}\text { Narcissism and } \\
\text { Dynamic Capability }\end{array}$ & -0.68 & -0.23 & 0.47 & 3.72 & 0.000 & $\begin{array}{l}\text { Negative } \\
\text { and Significant }\end{array}$ & $\begin{array}{l}\text { Not } \\
\text { Supported }\end{array}$ \\
\hline
\end{tabular}

Source: Amos 26.0 output on research data, 2020 


\section{References}

Ackerman, R., \& Prichard, D. (2011). Hearing Grasshoppers Jump: The Story of Raymond Akerman: New Africa Books.

Adendorff, C., Boshoff, C., \& Radloff, S. (2005). The impact of planning on good governance practices in South African Greek family businesses. Management Dynamics: Journal of the Southern African Institute for Management Scientists, 14(4), 34-46.

Allport, G. W. (1937). Personality: A psychological interpretation.

Asaju, K., Arome, S., \& Mukaila, I. (2014). Leadership crisis in Nigeria: The urgent need for moral education and value re-orientation. Public Administration Research, 3(1), 117.

Bednarz, J., Bieliński, T., Nikodemska-Wołowik, A., \& Otukoya, A. (2017). Sources of the competitive advantage of family enterprises: an international approach focusing on China, Nigeria and Poland. Entrepreneurial Business and Economics Review, 5(2), 123.

Bendig, D., Strese, S., Flatten, T. C., da Costa, M. E. S., \& Brettel, M. (2018). On micro-foundations of dynamic capabilities: a multi-level perspective based on CEO personality and knowledge-based capital. Long Range Planning, 51(6), 797-814.

Breznik, L., \& Lahovnik, M. (2014). Renewing the resource base in line with the dynamic capabilities view: a key to sustained competitive advantage in the IT industry. JEEMS Journal of East European Management Studies, 19(4), 453-485.

Cai, P. (2015). China's new economic crisis: Keeping the family business. The Asialink Essays, 7(1), 3-4.

Campbell, W. K., \& Miller, J. D. (2011). The handbook of narcissism and narcissistic personality disorder: Theoretical approaches, empirical findings, and treatments: John Wiley \& Sons.

Capron, E. W. (2004). Types of pampering and the narcissistic personality trait. Journal of Individual Psychology, $60(1)$.

Carpenter, M. A., Geletkanycz, M. A., \& Sanders, W. G. (2004). Upper echelons research revisited: Antecedents, elements, and consequences of top management team composition. Journal of Management, 30(6), 749778.

Chabrol, H., Van Leeuwen, N., Rodgers, R., \& Séjourné, N. (2009). Contributions of psychopathic, narcissistic, Machiavellian, and sadistic personality traits to juvenile delinquency. Personality and Individual Differences, 47(7), 734-739.

Chollet, B., Geraudel, M., Khedhaouria, A., \& Mothe, C. (2016). Market knowledge as a function of CEOs' personality: A fuzzy set approach. Journal of Business Research, 69(7), 2567-2573.

Coff, R. W. (2002). Human capital, shared expertise, and the likelihood of impasse in corporate acquisitions. Journal of Management, 28(1), 107-128.

Costa Jr, P. T. (1992). Revised NEO personality inventory and NEO five-factor inventory. Professional manual.

Denison, D. R. (1990). Corporate culture and organizational effectiveness: John Wiley \& Sons.

Díez-Martín, F., Prado-Roman, C., \& Blanco-González, A. (2013). Beyond legitimacy: legitimacy types and organizational success. Management decision.

Feist, J., Feist, G. J., \& Roberts, T. (2017). Teori Kepribadian Edisi Kedelapan. Jakarta: Salemba Humanika.

Finkelstein, S., Hambrick, D., \& Cannella, A. A. (1996). Strategic leadership. St. Paul: West Educational Publishing.

Forum, I. W. E. (1994). World Competitiveness Report. In.

Gaumer, C. J., \& Shaffer, K. J. (2018). Family business succession: impact on supplier relations and customer management. Human Resource Management International Digest, 26(6), 1-4.

Hambrick, D. C. (2007). Upper echelons theory: An update. In: Academy of Management Briarcliff Manor, NY 10510.

Hambrick, D. C., Finkelstein, S., \& Mooney, A. C. (2005). Executives sometimes lose it, just like the rest of us. Academy of management review, 30(3), 503-508.

Hambrick, D. C., \& Mason, P. A. (1984). Upper echelons: The organization as a reflection of its top managers. Academy of management review, 9(2), 193-206.

Harrison, J. S., Thurgood, G. R., Boivie, S., \& Pfarrer, M. D. (2019). How a CEO's Personality Affects Their Company's Stock Price. Harvard Business Review, 4.

Hiller, N. J., \& Hambrick, D. C. (2005). Conceptualizing executive hubris: the role of (hyper- ) core self- evaluations in strategic decision- making. Strategic management journal, 26(4), 297-319.

Howard, P. J., \& Howard, J. M. (1995). The Big Five Quickstart: An Introduction to the Five-Factor Model of Personality for Human Resource Professionals.

Kaplan, S. (2008). Cognition, capabilities, and incentives: Assessing firm response to the fiber-optic revolution. Academy of Management journal, 51(4), 672-695.

Kelleci, R., Lambrechts, F., Voordeckers, W., \& Huybrechts, J. (2019). CEO Personality: A Different Perspective on the Nonfamily Versus Family CEO Debate. Family Business Review, 32(1), 31-57. 
Kim, Namkoong, K., Ku, T., \& Kim, S. J. (2008). The relationship between online game addiction and aggression, self-control and narcissistic personality traits. European psychiatry, 23(3), 212-218.

Lee, Vargo, J., \& Seville, E. (2013). Developing a tool to measure and compare organizations' resilience. Natural hazards review, 14(1), 29-41.

Lin, H.-C., \& Rababah, N. (2014). CEO-TMT exchange, TMT personality composition, and decision quality: The mediating role of TMT psychological empowerment. The Leadership Quarterly, 25(5), 943-957.

Maas, G., \& Van der Merve, S. (2005). Family businesses in South Africa: a practical governance guide: GEB Consultants.

McAdams, D. P. (2016). The Mind of Donald Trump. Narcissism, Disagreeableness, Grandiosity-A Psychologist Investigates How Trump's Extraordinary Personality Might Shape His Possible Presidency. The Atlantic.

McCrae, R. R., \& Costa Jr, P. T. (1997). Personality trait structure as a human universal. American psychologist, 52(5), 509.

Miller, Lynam, D. R., \& Campbell, W. K. (2016). Measures of narcissism and their relations to DSM-5 pathological traits: A critical reappraisal. Assessment, 23(1), 3-9.

Mokhber, M., Gi Gi, T., Abdul Rasid, S. Z., Vakilbashi, A., Mohd Zamil, N., \& Woon Seng, Y. (2017). Succession planning and family business performance in SMEs. Journal of management development, 36(3), 330-347.

O'Reilly III, C. A., Caldwell, D. F., Chatman, J. A., \& Doerr, B. (2014). The promise and problems of organizational culture: CEO personality, culture, and firm performance. Group \& Organization Management, 39(6), 595-625.

Paulhus, D. L., \& Williams, K. M. (2002). The dark triad of personality: Narcissism, Machiavellianism, and psychopathy. Journal of research in personality, 36(6), 556-563.

Perret, S. T., Burnett, M. F., \& Richardson, W. B. (2017). Perceptions of the Importance of Succession Planning in Family Owned Businesses. Academy of Business Research Journal, 3, 44-63.

Pincus, A. L., \& Lukowitsky, M. R. (2010). Pathological narcissism and narcissistic personality disorder. Annual review of clinical psychology, 6, 421-446.

Porac, J. F., Thomas, H., \& Baden- Fuller, C. (2011). Competitive groups as cognitive communities: The case of Scottish knitwear manufacturers revisited. Journal of Management studies, 48(3), 646-664.

Reeves, M., \& Deimler, M. (2012). Adaptability: The new competitive advantage. Own the Future: 50 Ways to Win from the Boston Consulting Group, 19-26.

Robbins, S. P., Judge, T. A., \& Sanghi, S. (2007). Organizational Behavior [with CD]: Prentice-Hall of India.

Saville, P. (2016). From Obscurity to Clarity in Psychometric Testing: Selected Works of Professor Peter Saville: Routledge.

Schein, E. H. (2010). Organizational culture and leadership (Vol. 2): John Wiley \& Sons.

Schneider, B., \& Smith, D. B. (2004). Personality and organizations: Psychology Press.

Sherman, R. A., Nave, C. S., \& Funder, D. C. (2010). Situational similarity and personality predict behavioral consistency. Journal of Personality and Social Psychology, 99(2), 330.

Stafford, K., Bhargava, V., Danes, S. M., Haynes, G., \& Brewton, K. E. (2010). Factors associated with long-term survival of family businesses: Duration analysis. Journal of Family and Economic Issues, 31(4), 442-457.

Tamborski, M., \& Brown, R. P. (2011). The measurement of trait narcissism in social-personality research. The handbook of narcissism and narcissistic personality disorder: Theoretical approaches, empirical findings, and treatments, 133-140.

Tantrabundit, P., \& Narkbunnum, W. (2018). The Effects of CEO's Personality on Knowledge Transfer and Innovative Performance in Thai SMEs. Paper presented at the 2018 3rd Technology Innovation Management and Engineering Science International Conference (TIMES-iCON).

Teece, D. J., Pisano, G., \& Shuen, A. (1997). Dynamic capabilities and strategic management. Strategic management journal, 18(7), 509-533.

Van der Westhuizen, J., \& Garnett, A. (2014). The correlation of leadership practices of first and second generation family business owners to business performance. Mediterranean Journal of Social Sciences, 5(21), 27.

Venter, E. (2003). The succession process in small and medium-sized family businesses in South Africa.

von den Driesch, T., Da Costa, M. E. S., Flatten, T. C., \& Brettel, M. (2015). How CEO experience, personality, and network affect firms' dynamic capabilities. European Management Journal, 33(4), 245-256.

Wang, \& Chen, X. (2019). Recognizing CEO personality and its impact on business performance: Mining linguistic cues from social media. Information \& Management, 103173.

Zopiatis, A., \& Constanti, P. (2012). Extraversion, openness and conscientiousness: The route to transformational leadership in the hotel industry. Leadership \& Organization Development Journal, 33(1), 86-104. 